\title{
ENZYMATIC ACTIVITY OF PSYCHROTOLERANT ANTARCTIC BACTERIA
}

\author{
N.V. Borzova, G.V. Gladka, O.V. Gudzenko, \\ V.M. Hovorukha, O.B. Tashyrev \\ Zabolotny Institute of Microbiology and Virology, NAS of Ukraine, \\ 154 Acad. Zabolotny Str., Kyiv, 03143, Ukraine \\ e-mail:nv_borzova@bigmir.net
}

The Antarctic region has significant potential to study the biodiversity of microorganisms and to search for bacterial producers of glycolytic and proteolytic enzymes with new properties. The aim was to study the extracellular glycosidase and proteolytic activity of four bacteria strains isolated from black lichens of the cliffs of Galindez Island in the Antarctic. Methods. Cultures of bacteria were grown in submerged conditions at a temperature of 15 and $26^{\circ} \mathrm{C}$ for $48 \mathrm{~h}$. The synthetic and natural substrates such as p-nitrophenyl-glycosides, soluble starch, gelatin, casein and Elastin-Congo red were used to study the enzymatic activity of bacteria. Results. All studied strains showed $\alpha$-fucosidase activity. Microbacterium foliorum, Sporosarcina aquimarina and Rothia sp. exhibited $\alpha$-, $\beta$-xylosidase, $\beta$-glucosidase or $\beta$ - $N$-acetylglucosaminidase activity in different ratios. That may indicate the presence of the enzymatic complex of hydrolysis of lichenan and xylan, which are part of polysaccharides of plants and lichens. P. fluorescens and M. foliorum also showed gelatinase activity. The enzymatic activity of bacteria was noted to be higher in the case of cultivating at $15{ }^{\circ} \mathrm{C}$ compared to $26^{\circ} \mathrm{C}$. The $\alpha$-xylosidase of $M$. foliorum was optimally active at $\mathrm{pH} 6.0$ and $35^{\circ} \mathrm{C}$, the $\alpha$-xylosidase of Rothia $\mathrm{sp}$ - at $\mathrm{pH} 6.5$ and $35^{\circ} \mathrm{C}$. High level of stability was shown for these enzymes in the $\mathrm{pH}$ range from 4.0 to 7.0 and temperature from 15 to $35^{\circ} \mathrm{C}$ during $24 \mathrm{~h}$. Conclusions. Antarctic lichens can be a source of bacterial producers of polysaccharide degrading enzymes with new properties and low temperature optimum. The Antarctic cold environment provides the great opportunities to study the adaptive mechanisms of microorganisms and their enzymatic systems in order to develop new biotechnologies.

Keywords: Pseudomonas fluorescens, Microbacterium foliorum, Sporosarcina aquimarina, Rothia sp., glycosidase and protease activity.

The Antarctic is a unique region in terms of climatic conditions. It is characterize by low temperature and sharp fluctuations of temperature range, low availability of nutrients, lack of soil cover, high levels of solar radiation and limited anthropogenic impact [1-3]. The remoteness of the Antarctic and the harshness of its climate are the major obstacles to study of the continent's ecosystems. However, more and more research on the diversity and the role of marine and terrestrial microorganisms in the formation and functioning of the Antarctic ecosystem appears in recent years [4, 5]. To date, hundreds of species of bacteria, yeast, micromycetes isolated from various ecological niches in the Antarctic have been described. They include cosmopolitan, circular and endophytic species, but all of them share the ability to adapt to the harsh living conditions in the region.

Despite the geographical remoteness of the Antarctic islands and the extreme climatic con- ditions there, the most of the isolated Antarctic microorganisms belong to the traditional classical taxa distributed in different regions of the Earth with a temperate climate. It is possible that most of them were brought to the Antarctic via the migration of birds, as a result of anthropogenic pollution at existing stations, etc. In addition, bacterial communities in the Antarctic at the level of high taxonomic ranks (classes) were shown to be characterized by high stability. They were represented by microorganisms typical for the soils of the globe $[6,7]$.

Cliffs are an extremely interesting ecosystem formed on the continent and adjacent islands. They are never covered with snow. This fact is their distinct feature. Therefore, their biocenoses are affected by extreme factors throughout the year, which contributes to the formation of specific groups of extremophilic microorganisms. These bacteria and fungi play a key role in the polar ecosystem and 
are major components of the Antarctic biomass [8]. The stability of the functioning of psychrophilic and psychrotolerant microorganisms under the influence of extreme factors is one of their key characteristics. The complex range of structural and functional adaptations provides successful growth of extremophiles under the conditions of low temperature and humidity [9-12]. There are also data on the isolation of bacteria adapted to extreme conditions from the Antarctic. They are adapted to temperature fluctuations in a wide range, which has considerable advantages for their colonization of various ecological niches [13].

The specific conditions of the Antarctic are of the particular interest to search for new strains of microorganisms that have high biotechnological potential and unique biochemical properties [14]. Microorganisms distributed in low-temperature regions may have certain biotechnological advantages over mesophilic producers of industrially important bioactive compounds [15]. Adaptation to low temperatures is accompanied by the synthesis of enzymes being active at lower temperatures, which has a significant economic effect. Today there are data on a wide range of hydrolytic enzymes of extremophiles in the literature: lipase, protease, amylase, cellulase, xylanase, pectinase, chitinase $[16,17]$. The unique biochemical properties, wide range of activity and stability of such enzymes contribute to the active search for the producers of biologically active compounds among the Antarctic microorganisms. In addition, extremophile enzymes are often resistant to several critical factors. This property greatly expands their application in various industrial biotechnologies, especially in the medical, pharmaceutical, cosmetic industries, as well as in food technologies for biotransformation of raw materials of various origins.

The goal of this study was to investigate the extracellular glycosidase and proteolytic activity of four strains of bacteria isolated from black lichens of the cliffs of Galindez island in the Antarctic.

Materials and methods. The objects of the study were glycosidase and protease activity of Pseudomonas fluorescens 180n1, Microbacterium foliorum $181 \mathrm{n} 2$, Sporosarcina aquimarina $188 \mathrm{n} 2$ and Rothia sp. 190n2, that were isolated from black lichens of the climbing wall of Galindez Island during seasonal biological research at the Ukrainian Antarctic Station "Academik Vernadsky". The strains are stored in the collection of live cultures of the Zabolotny Institute of Microbiology and Virology of the National Academy of Sciences of Ukraine. They are aerobic, chemoorganotrophic, psychro- and halotolerant bacteria (Table 1).

\section{Table 1}

The microorganisms isolated from the terrestrial ecosystems of Galindez Island of Western Antarctica

\begin{tabular}{|c|c|c|c|c|c|}
\hline Strain & Isolation source & $\begin{array}{c}\text { Observation } \\
\text { points }\end{array}$ & $\begin{array}{c}\text { Pigmentation } \\
\text { of colonies }\end{array}$ & $\begin{array}{l}\text { Growth in } \\
\text { a range } \mathrm{T},{ }^{\circ} \mathrm{C}\end{array}$ & $\begin{array}{c}\text { Growth in } \\
\text { a range } \mathrm{NaCl}, \%\end{array}$ \\
\hline $\begin{array}{l}\text { Pseudomonas } \\
\text { fluorescens } 180 \mathrm{n} 1\end{array}$ & \multirow{4}{*}{$\begin{array}{l}\text { Black lichens of } \\
\text { the climbing wall }\end{array}$} & Tsk-1 & Non-pigmented & $1-30$ & 2.5 \\
\hline $\begin{array}{l}\text { Microbacterium } \\
\text { foliorum } 181 \mathrm{n} 2\end{array}$ & & Tsk-2 & Lemon-yellow & $1-30$ & 4.0 \\
\hline $\begin{array}{l}\text { Sporosarcina } \\
\text { aquimarina } 188 \mathrm{n} 2\end{array}$ & & Tsk-9 & Pale pink & $1-30$ & 5.0 \\
\hline Rothia sp. 190n2 & & Tsk-11 & White & $5-30$ & 10.0 \\
\hline
\end{tabular}

The spectrum of glycosidase and proteolytic activities was studied in the supernatant of the culture fluid of bacteria. The strains were grown under submerged conditions at a temperature of 15 and $26^{\circ} \mathrm{C}$ for $48 \mathrm{~h}$ on medium 1 and medium 2 of the following compositions ( $\mathrm{g} / \mathrm{l})$ : 1) rhamnose 5.0 ; urea - 1.0; yeast autolysate $-0.3 ; \mathrm{KH}_{2} \mathrm{PO}_{4}-$ $0.5 ; \mathrm{MgSO}_{4} \times 7 \mathrm{H}_{2} \mathrm{O}-0.25 ; \mathrm{KCl}-0.3 ; \mathrm{pH} 6.0$; 2) soy flour -20.0 ; urea -1.0 ; yeast autolysate $0.3 ; \mathrm{KH}_{2} \mathrm{PO}_{4}-0.5 ; \mathrm{MgSO}_{4} \times 7 \mathrm{H}_{2} \mathrm{O}-0.25 ; \mathrm{KCl}-$
$0.3 ; \mathrm{pH}$ 6.0. Medium 3 was used to study the proteolytic activity $(\mathrm{g} / \mathrm{l})$ : maltose -1.0 ; gelatin 10.0 ; urea -1.0 ; yeast autolysate $-0.3 ; \mathrm{KH}_{2} \mathrm{PO}_{4}-$ $0.5 ; \mathrm{MgSO}_{4} \times 7 \mathrm{H}_{2} \mathrm{O}-0.25 ; \mathrm{KCl}-0.3 ; \mathrm{pH} 6.0$. After the fermentation, the biomass was separated by centrifugation at $5000 \mathrm{~g}, 30 \mathrm{~min}$.

Upon examining the glycosidase activities appropriate synthetic substrates were used: $p$-nitrophenyl-2-acetamido-2-deoxy- $\alpha-D$-galactopyranoside, $p$-nitrophenyl-2-acetamido-2- 
deoxy- $\beta-D$-galactopyranoside, $p$-nitrophenyl-2acetamido-2-deoxy- $\alpha$ - and $\beta$ - $D$-glucopyranoside ("Koch-Light", Great Britain), $p$-nitrophenyl- $\alpha$ and $\beta$ - $D$-galactopyranoside, $p$-nitrophenyl- $\alpha$ and $\beta$ - $D$-glucopyranoside, $p$-nitrophenyl- $\alpha$ - and - $\beta$ - $D$-xylopyranoside, $p$-nitrophenyl- $\alpha-D$-manopyranoside, $p$-nitrophenyl- $\alpha$ - $D$-fucopyranoside, and $p$-nitrophenyl- $\beta$-glucuronoside ("Sigma", USA). To determine the activity $0.1 \mathrm{ml}$ of the enzyme solution was mixed with $0.2 \mathrm{ml} 0.1 \mathrm{M}$ phosphate-citrate buffer (PCB), pH 5.2 and $0.1 \mathrm{ml} 0.01 \mathrm{M}$ substrates solution in $\mathrm{PCB}$. The reaction mixture was incubated for $10 \mathrm{~min}$ at $37^{\circ} \mathrm{C}$. The reaction was stopped by adding $2 \mathrm{ml}$ of $1 \mathrm{M}$ sodium bicarbonate. The control sample was mixed with the same reaction components, but in the reverse order. The amount of released nitrophenol as a result of hydrolysis was determined using colorimetric analysis by the absorption at $400 \mathrm{~nm}$. One unit of enzyme activity $(\mathrm{U})$ was defined as the amount of enzyme that releases $1 \mu \mathrm{M}$ of $p$-nitrophenol per min at $37^{\circ} \mathrm{C}$ in 0.1 M PCB, pH 6.0.

To determine the amylolytic activity the strains were grown on solid agar medium with soluble starch for 24-48 h. The amylolytic activity was evaluated after staining of the plates with iodine solution to reveal the zones of starch hydrolysis. The efficiency of starch hydrolysis was determined by the ratio of the colony diameter to the diameter of the enlightenment zone.

The proteolytic activity was determined by the Anson's method, modified by Petrova with casein as the substrate [18]. The elastase activity was evaluated using colorimetric analysis according to the intensity of staining of the solution after the enzymatic hydrolysis of the Elastin-Congo red [19]. Screening of the strains for the gelatinase activity was carried out by growing bacteria in gelatin plates at $20^{\circ} \mathrm{C}$ for $48 \mathrm{~h}$. The activity of the strains was evaluated by their ability to decompose gelatin.

Culture filtrates of $M$. foliorum $181 \mathrm{n} 2$ and Rothia sp. 190n2 grown on medium 2 for $48 \mathrm{~h}$ at 15 and $26{ }^{\circ} \mathrm{C}$ were mixed with dry ammonium sulfate salt up to $90 \%$ saturation under $\mathrm{pH}$ control. The mixture was incubated for $24 \mathrm{~h}$ at $4{ }^{\circ} \mathrm{C}$ followed by centrifugation at $5000 \mathrm{~g}, 30 \mathrm{~min}$. Precipitate was dialyzed against $0.1 \mathrm{M} \mathrm{PCB}, \mathrm{pH}$ 6.0 and was applied to the column $(1.3 \times 50 \mathrm{~cm})$ with Sepharose 6B. The fractions with $\alpha$-xylosidase activity were combined and dialyzed against $0.1 \mathrm{M}$ PCB (pH 6.0). The dialysate was used as crude enzyme preparation for other studies.
The optimum $\mathrm{pH}$ for the activities of $\alpha$-xylosidase was determined by incubating the enzyme preparation with $p$-nitrophenyl- $\alpha-D$ xylopyranoside in $0.1 \mathrm{M} \mathrm{PCB}$ and $0.01 \mathrm{M}$ Tris$\mathrm{HCl}$ buffers at the $\mathrm{pH}$ range from 3 to 9 . The $\mathrm{pH}$ stability was evaluated by preincubation of the enzymes in PCB over a pH range from 4 to 7 at 20 $30{ }^{\circ} \mathrm{C}$. Activities were measured after $24 \mathrm{~h}$ using the standard protocol. The optimum temperature of $\alpha$-xylosidase was determined by incubating the assay mixture for $10 \mathrm{~min}$ at temperature ranging from 5 to $60{ }^{\circ} \mathrm{C}$. Thermal stability was measured by preincubation of the enzymes at the optimum $\mathrm{pH}$ at different temperatures $(10,15,20,25,30,40$, $50{ }^{\circ} \mathrm{C}$ ) with the exposition time of $90 \mathrm{~min}$.

All experiments were replicated 3-5 times. Analysis of the data was done using Student's t-criterion. Values were considered significant at $\mathrm{P}<0.05$.

Results. We used bacteria previously isolated from phytocenoses of Galindez Island. Recent studies have demonstrated that lichens are a stable microenvironment for diverse communities of different bacteria [3, 4]. Lichen species in Antarctica are components of surface lithobiontic communities or colonize of lithic substrata. Various bacterial genera were found distributed among the different lichens studied, suggesting there is no required and/or specific association between lichens and bacteria. As reported [10,11], lichens represent an extremely rich reservoir for the isolation of a wide diversity of bacteria, many of them representing a rich source of secondary metabolites. Pseudomonas, Microbacterium, Sporosarcina and Rothia are abundant species in the rhizosphere of plant, they are frequently found in a variety of Antarctic biotopes and substrates. We investigated the spectrum of 13 exoglycosidase activities in deep culture of bacteria. P. fluorescens $180 \mathrm{n} 1$ was characterized only by the $\alpha$-fucosidase activity, and Rothia sp. 190n 2 - $\alpha$-fucosidase, $\alpha$-xylosidase and $\beta$-glucosidase activities (Fig. 1). Five different activities were observed in the supernatant of the culture fluid of M. foliorum $181 \mathrm{n} 2$ and $S$. aquimarina $188 \mathrm{n} 2$. It should be noted that the $\alpha$-fucosidase activity was detected in all studied bacterial strains. The presence of $\alpha$-xylosidase was noted in three strains. M. foliorum 181n2 and Rothia sp. 190n2 were characterized by its level of 3.9 and $4.1 \mathrm{U} / \mathrm{ml}$ (Fig. 3).

The presence of $\alpha$ - and $\beta$-xylosidase, as well as $\beta$-glucosidase and $\beta$-N-acetylglucosaminidase 
activity in these bacteria may indicate the presence of the enzymatic complex of lichenans and xylans hydrolysis, which are part of polysaccharides of plants and lichens. Thus, due to these activities microorganisms might be provided by the sources of nutrients and energy existing on rocky surfaces overgrown with lichen. Amylase activity was absent in all studied bacteria.
High gelatinase activity was observed in P. fluorescens $180 \mathrm{n} 1$ and Rothia sp. 190n2, the diameter of the hydrolysis zone was 15 and $35 \mathrm{~mm}$ after incubation for $24 \mathrm{~h}, 15^{\circ} \mathrm{C}$ (Fig. 2), but the elastase and caseinolytic activity were absent. M. foliorum $181 \mathrm{n} 2$ and $S$. aquimarina $188 \mathrm{n} 2$ showed a very low ability to hydrolyze all provided protein substrates. This activity can be explained by the source of

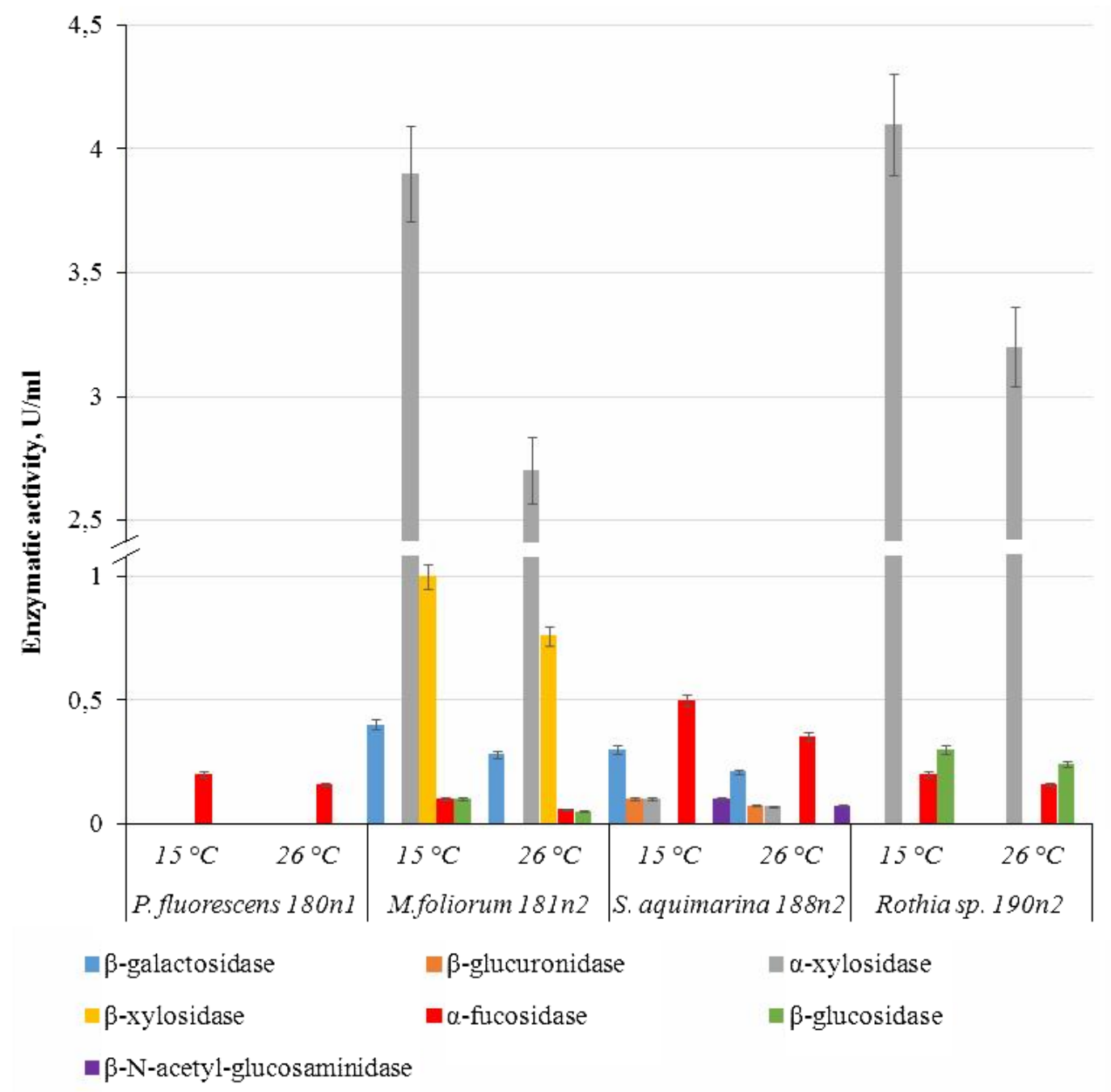

F i g. 1. The spectrum of enzymatic activity of Antarctic bacteria at $15{ }^{\circ} \mathrm{C}$ compared to $26^{\circ} \mathrm{C}$

A

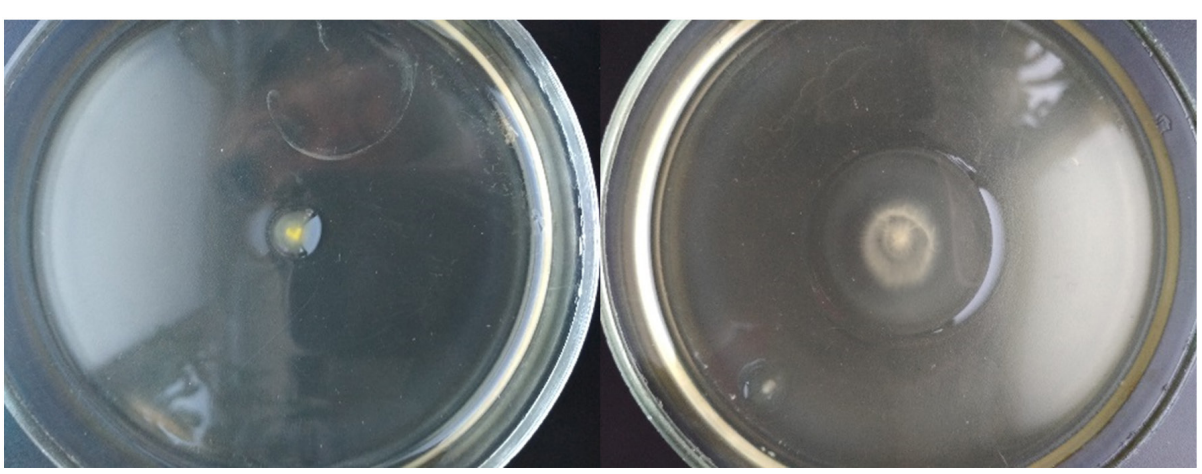

F i g. 2. The hydrolysis of gelatin: A) M. foliorum $181 \mathrm{n} 2$, B) P. fluorescens 180n1 (incubation for $24 \mathrm{~h}, 16^{\circ} \mathrm{C}$ ) 
isolation of all four bacteria. The extracellular proteases are mainly inducible enzymes, and the rocky surfaces from which the cultures were isolated could contain very small amounts of protein substrates.

It should also be noted that the enzymatic activity of all strains depended on the growing temperature, and was $20-42 \%$ higher at $15{ }^{\circ} \mathrm{C}$ compared to $26{ }^{\circ} \mathrm{C}$ (Fig. 1).

Since the two strains (M. foliorum $181 \mathrm{n} 2$ and Rothia sp. 190n2) exhibited high $\alpha$-xylosidase activity, we studied some of the physical properties of their enzymes. The partially purified $\alpha$-xylosidases of M. foliorum $181 \mathrm{n} 2$ and Rothia sp.

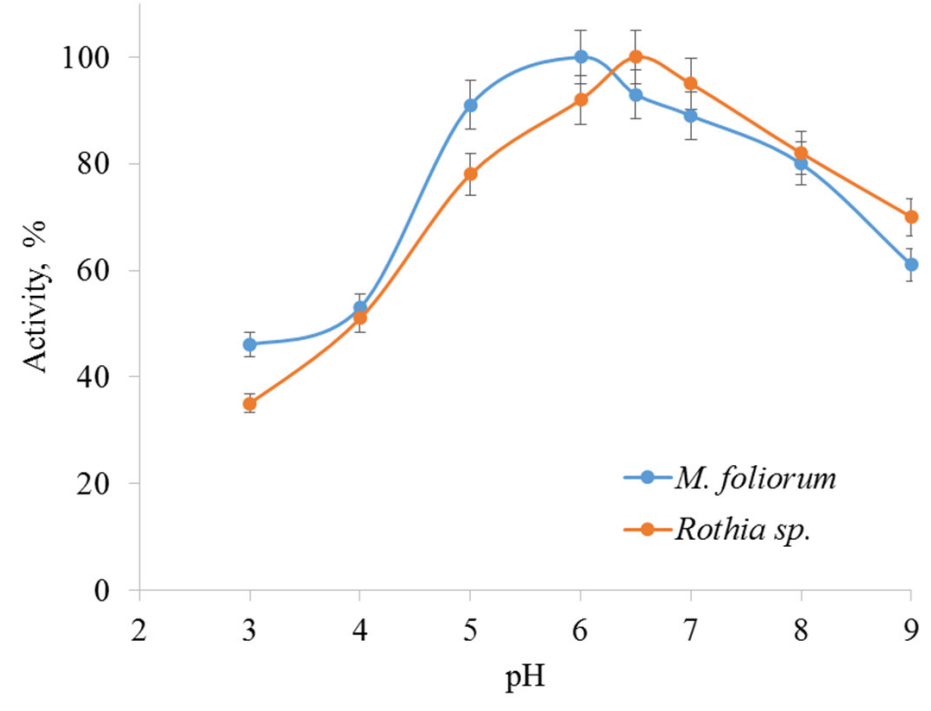

F i g. 3. The effects of pH on $\alpha$-xylosidase activity of Antarctic bacteria

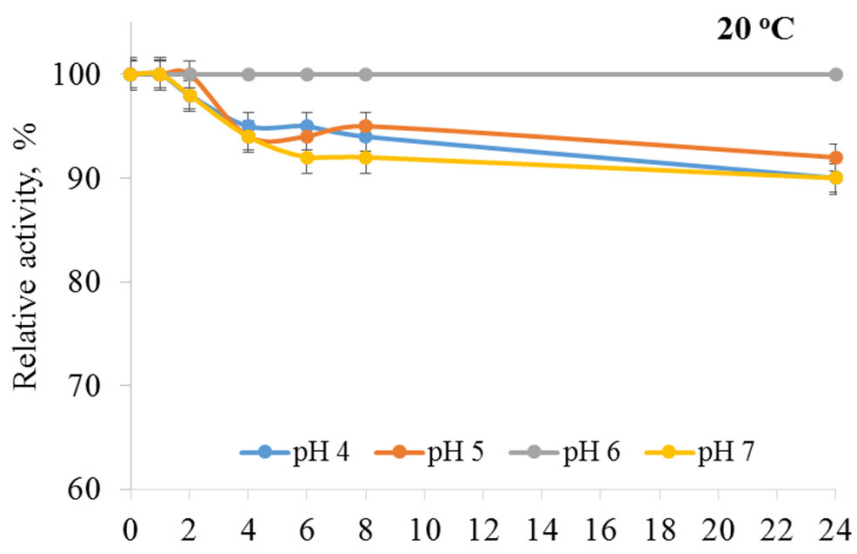

Time, h

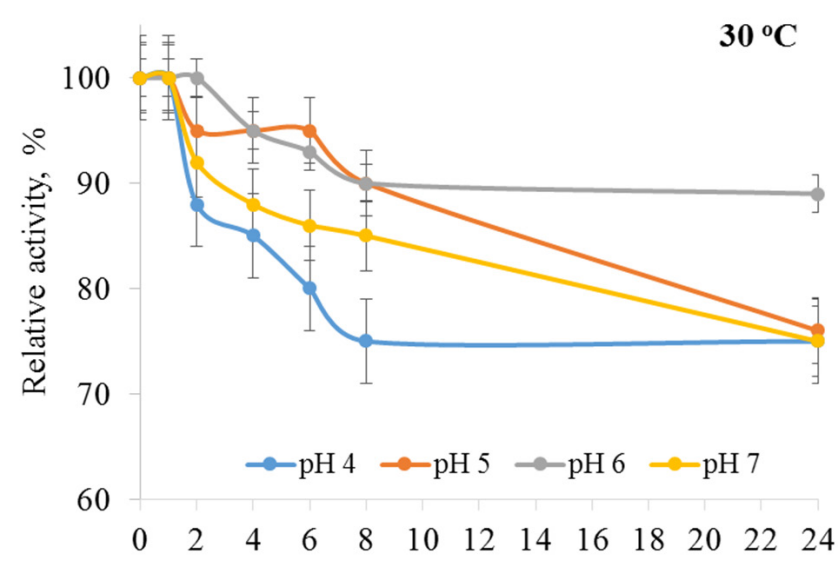

Time, $\mathrm{h}$

F i g. 4. The effect of $\mathrm{pH}$ on stability of $\alpha$-xylosidases of $M$. foliorum $181 \mathrm{n} 2$ at 20 and $30{ }^{\circ} \mathrm{C}$ 
190n2 showed high activity in $\mathrm{pH}$ diapason 5-7. Optimum $\mathrm{pH}$ for the hydrolysis of $p$-nitrophenyl$\alpha$ - $D$-xylopyranoside by $M$. foliorum $181 \mathrm{n} 2$ enzyme preparation was 6.0 at $37{ }^{\circ} \mathrm{C}$, optimum $\mathrm{pH}$ for $\alpha$-xylosidases of Rothia sp. 190n2 was found to be 6.5 (Fig. 3). Similar results were also reported for the other bacterial xylanases, where optimum $\mathrm{pH}$ range was $5-7[12,15]$. The stability of the $\alpha$-xylosidases of M. foliorum $181 \mathrm{n} 2$ and Rothia sp. 190n2 was determined by the preincubation of the preparations in various buffers at different $\mathrm{pH}$ for $24 \mathrm{~h}$ at 20 and $30^{\circ} \mathrm{C}$. The enzymes were relatively stable a $\mathrm{pH}$ range from 4 to 7 (retained $90-100 \%$ of activity at $20{ }^{\circ} \mathrm{C}$ and $75-90 \%-$ at $30^{\circ} \mathrm{C}$ ) (Fig. 4). In addition, high level of stability was shown for these enzymes if stored as $3 \mathrm{M}$ solution of ammonium sulfate. Specifically, during 6 month of storage at $4{ }^{\circ} \mathrm{C}$ no reduction of activity was determined.

The activity of $\alpha$-xylosidases of $M$. foliorum $181 \mathrm{n} 2$ and Rothia sp. 190n2 was determined at different temperatures $10-50{ }^{\circ} \mathrm{C}$ (Fig. 5). The optimum temperature for enzyme activity was noted at $35{ }^{\circ} \mathrm{C}$. The enzymes showed the same activity in temperature range from 15 to $35{ }^{\circ} \mathrm{C}$. Beyond this temperature, activity quickly reduced.

Thus, our preliminary results indicate the psychrotolerance of studied bacterial $\alpha$-xylosidases and the prospects for their use for various biotechnological applications at low temperatures.

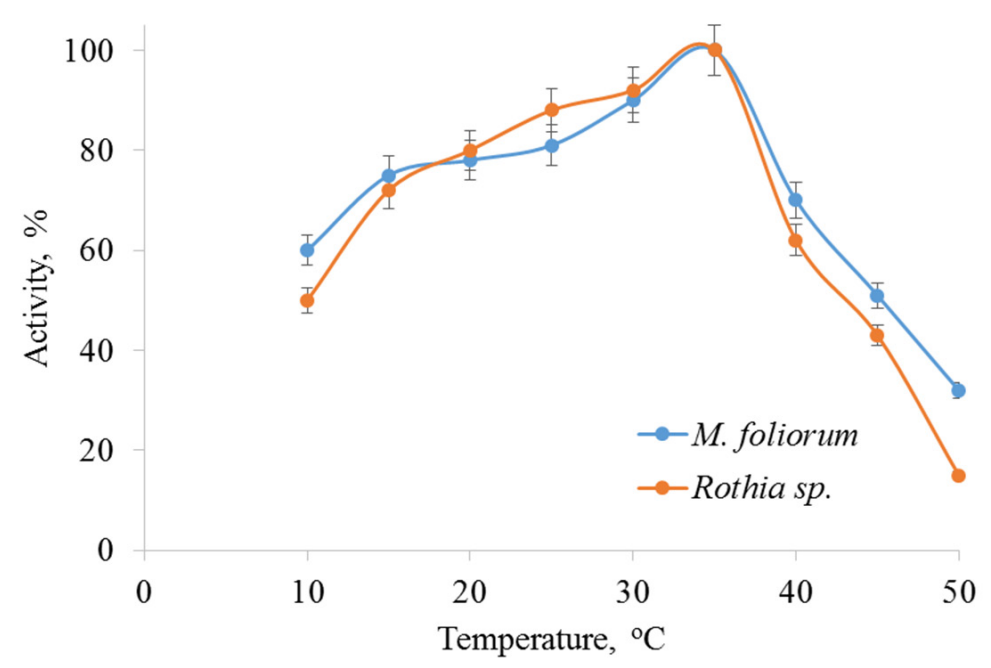

F i g. 5. The effect of temperature on the $\alpha$-xylosidase activity of Antarctic bacteria

Discussion. The number of studies of the Antarctic microbiome is growing steadily in recent years. Both the biodiversity of microorganisms inhabiting the Antarctica continent and the surrounding coastal microcenoses, which are under the influence of the world's oceans, are studied.

The role of lichens in the formation of biogeocenoses of Antarctica is difficult to overestimate. Due to their sensitivity to changes in the balance of natural cycles and high adaptive potential at the same time, lichens are not only bioindicators of the ecological state of the environment, but they are also able to master ecotopes and substrates inaccessible to higher life forms. Due to the dominance of lichens, mosses and cyanobacteria, unique ecological niches for the growth of microorganisms in the Antarctic are being created.

The Antarctic microbiome is considered a source of extremophilic microorganisms with the ability to survive in extreme conditions, which means they can have huge biotechnological potential.

We study psychrotolerant (temperature range of growth $1-5-30{ }^{\circ} \mathrm{C}$ ) and halophilic (growth in a medium containing $2.5-5 \% \mathrm{NaCl}$ ) Antarctic strains of bacteria. Extracellular hydrolase activity is an integral part of the adaptation of such microorganisms to the colonization of terrestrial and aquatic ecosystems [14-16]. Glycosidases and proteases combine a large and complex group of enzymes that play important trophic and regulatory roles both at the cellular level and the ecosystem as a whole $[17,20]$. They are a physiologically integral element of cell function that allows adapting and surviving in different conditions including trophically limited ones. The range of enzymatic activity of a microorganism may depend on many factors, primarily on the genetic and physiological characteristics of the bacterium. The study of the extracellular glycosidase activity of 
bacteria isolated from one ecological niche showed their ability to produce a number of glycosidases, but the spectrum of glycosidase activities of the studied strains differed significantly.

Despite the different taxonomic origins of the studied bacteria, they have some common features. Thus, all strains showed $\alpha$-fucosidase, and three of the four $-\alpha$-xylosidase activity. P. fluorescens $180 \mathrm{n} 1$ strain was the least active. But together with the low glycosidase activity this strain showed the highest activity to hydrolyze gelatin. In general, all strains isolated from black lichens showed some activity of the cellulase and hemicellulase complex and revealed almost no proteolytic activity. These data once more confirm modern ideas about the inducible nature of the synthesis of extracellular hydrolases and the need for targeted search for enzyme producers in sources rich with the relevant substrates [21]. The strains of M. foliorum $181 \mathrm{n} 2$ and Rothia sp. 190n2 showed a high level of $\alpha$-xylosidase activity comparable to the activity of such producers as Cellvibrio japonicas, Sul-

\section{ЕНЗИМАТИЧНА АКТИВНІСТЬ АНТАРКТИЧНИХ БАКТЕРІЙ}

\section{Н.В. Борзова, Г.В. Гладка, О.В. Гудзенко, В.М. Говоруха, О.Б. Таширев}

\author{
Інститут мікробіології і вірусологіі \\ ім. Д. К. Заболотного НАН України, \\ вул. Академіка Заболотного, 154, \\ Київ, 03143, Украӥна
}

\section{Резюме}

Антарктичний регіон має значний потенціал для вивчення біорізноманіття мікроорганізмів та пошуку бактеріальних продуцентів гліколітичних та протеолітичних ензимів 3 новими властивостями. Метою дослідження було вивчення позаклітинної глікозидазної та протеолітичної активності чотирьох штамів бактерій, виділених із чорних лишайників скель острова Галіндез в Антарктиці. Методи. Культури бактерій вирощували у глибинних умовах при 15 та $26^{\circ} \mathrm{C}$ протягом 48 год. Для дослідження глікозидазної активності використовували середовища наступного складу (у г/л): 1) рамноза - 5,0; сечовина - 1,0; дріжджовий автолізат - 0,$3 ; \mathrm{KH}_{2} \mathrm{PO}_{4}-$ 0,$5 ; \mathrm{MgSO}_{4} \times 7 \mathrm{H}_{2} \mathrm{O}-0,25 ; \mathrm{KCl}-0,3 ; \mathrm{pH} 6,0 ; 2$ ) coєве борошно - 20,0; сечовина - 1,0 ; дріжджовий автолізат - 0,$3 ; \mathrm{KH}_{2} \mathrm{PO}_{4}-0,5 ; \mathrm{MgSO}_{4} \times 7 \mathrm{H}_{2} \mathrm{O}-$ 0,$25 ; \mathrm{KCl}-0,3 ; \mathrm{pH} 6,0$. Вивчення протеолітичної активності проводили після вирощування на folobus solfataricus, Aspergillus niger [22, 23]. The enzymatic activity of the strains was higher when growing at lower temperatures. This property opens wide prospects for the involvement of psychrotolerant strains in the technological processes of enzymes obtaining. In addition to the more cost-effective process of obtaining, these enzymes may have other advantages such as high activity at low temperatures. This property can be widely used in temperate climate for efficient waste treatment.

Thus, the isolation and study of new bacterial strains from different ecotopes of the Antarctic region expand our understanding of the limits of adaptation of microorganisms, their biodiversity and biotechnological potential. Antarctic lichens can be a source of bacterial producers of polysaccharide degrading enzymes with new properties and low thermal optimum. That will optimize the conditions of the hydrolysis process and expand the application of such biocatalysts.

середовищі $з$ желатином. Для визначення ензиматичної активності бактерій використовували синтетичні та природні субстрати: $n$-нітрофенілглікозиди, розчинний крохмаль, желатин, казеїн та конго-род еластин. Виділення ензимних препаратів M. foliorum та Rothia sp. проводили шляхом осадження $90 \%$ сульфатом амонію з фільтрата культуральної рідини продуцента після культивування. Визначення термооптимуму проводили в діапазоні температур $10-50{ }^{\circ} \mathrm{C}$, $\mathrm{pH}$-оптимуму в діапазоні рН від 3,0 до 9,0. Результати. Всі досліджені штами проявляли $\alpha$-фукозидазну активність. M. foliorum, S. aquimarina та Rothia sp. проявляли $\alpha$ - та $\beta$-ксилозидазну, $\beta$-глюкозидазну та(або) $\beta$-N-ацетилглюкозамінідазну активності у різних співвідношеннях. Відмічена активність може свідчити про присутність у цих бактерій ензиматичного комплексу гідролізу ліхенанів та ксиланів, які є складовою полісахаридів рослин та лишайників. Культури P. fluorescens та M. foliorum також ефективно гідролізували желатин. Висока $\alpha$-ксилозидазна активність M. foliorum $181 \mathrm{n} 2$ (3,9 од/мл) та Rothia sp. 190n2 (4,1 од/мл) дозволяе розглядати ці штами в якості нових продуцентів $\alpha$-ксилозидази для гідролізу ксиланів та ксилоглюканів. Слід зазначити, що ензиматична активність всіх досліджених штамів була вище на 20-42 \% за культивування при $15{ }^{\circ} \mathrm{C}$ у порівнянні з вирошуванням при $26{ }^{\circ} \mathrm{C}$. Було досліджено деякі фізичні 
властивості ензимних препаратів грубої очистки з $\alpha$-ксилозидазною активністю, виділених із культуральної рідини M. foliorum та Rothia sp. Термооптимум $\alpha$-ксилозидазної активності M. foliorum та Rothia sp. спостерігався при $35^{\circ} \mathrm{C}$, а рН оптимум складав 6,0 та 6,5 відповідно. Обидва ензимні препарати показали високий рівень стабільності в діапазоні рН від 4,0 до 7,0 та термостабільність при температурі $15-35{ }^{\circ} \mathrm{C}$. Було відмічено збереження активності на рівні 75-100 \% за цих умов протягом 24-х годин інкубування. Обидва ензимні препарати проявляли високу стабільність під час збереження при 4 ㄷ. Висновки. Антарктичні ли-

1. Adlam LS, Balks MR, Seybold CA, Campbell DI. Temporal and spatial variation inactive layer depth in the McMurdo Sound Region, Antarctica. Antarct Sci . 2010; 22(1):45-52.

2. Thomas DN, Fogg GE, Convey P, Fritsen CH, Gili J-M, Gradinger R, Laybourn-Parry J, Reid K, Walton DWH. The biology of Polar Regions. Oxford: Oxford University Press; 2008.

3. Yergeau E, Newsham KK, Pearce DA, Kowalchuk GA. Patterns of bacterial diversity across a range of Antarctic terrestrial habitats. Environ Microbiol. 2007; 9(11):2670-2682.

4. Cowan DA, Makhalanyane TP, Dennis PG, Hopkins DW. Microbial ecology and biogeochemistry of continental Antarctic soils. Front Microbiol. $2014 ; 5: 154$.

5. Nunez-Pons L, Avila C, Romano G, Verde C, Giordano D. UV-protective compounds in marine organisms from the Southern Ocean. Mar Drugs. 2018; $16: 336$.

6. Bottos EM, Scarrow JW, Archer SDJ, McDonald IR, Cary SC. Antarctic terrestrial microbiology. In: Cowan DA, editor. Bacterial community structures of antarctic soils. Berlin, Heidelberg: Springer-Verlag; 2014. p. 9-33.

7. Pessi IS, Osorio-Forero C, Galvez EJ, Simoes FL, Simoes JC, Junca H, Macedo AJ. Distinct composition signatures of archaeal and bacterial phylotypes in the Wanda Glacier forefield, Antarctic Peninsula. FEMS Microbiol Ecol. 2015; 91(1):1-10.

8. Pointing SB, Chan Y, Lacap DC, Lau MC, Jurgens JA, Farrell RL. Highly specialized microbial diversity in hyper-arid polar desert. Proc Natl шайники можуть бути джерелом бактеріальних продуцентів полісахарид-деградувальних ензимів 3 новими властивостями та низьким температурним оптимумом дії. Низькотемпературний антарктичний регіон відкриває широкі можливості для дослідження адаптивних механізмів мікроорганізмів та їхніх ензиматичних систем з метою розробки нових біотехнологій.

Ключові слова: Pseudomonas fluorescens, Microbacterium foliorum, Sporosarcina aquimarina, Rothia sp., глікозидазна та протеолітична активності, $\alpha$-ксилозидаза.

Acad Sci USA. 2009; 106:19964-19969.

9. Hughes KA, Cowan DA, Wilmotte A. Protection of Antarctic microbial communities - 'out of sight, out of mind'. Front Microbiol 2015; 6:151. https://doi.org/10.3389/fmicb.2015.00151

10. Margesin R, Miteva V. Diversity and ecology of psychrophilic microorganisms. Res Microbiol. 2011; 162:346-361.

11. Niederberger TD, McDonald IR, Hacker AL, Soo RM, Barrett JE, Wall DH, Cary SC. Microbial community composition in soils of Northern Victoria Land, Antarctica. Environ Microbiol. 2008; 10:1713-1724.

12. Russell NJ. Molecular adaptations in psychrophilic bacteria: potential for biotechnological applications. Adv Biochem Eng Biotechnol. 1998; 61:1-21.

13. Chattopadhyay MK. Mechanism of bacterial adaptation to low temperature. J Biosci. 2006; 31:57-165.

14. Silva TR, Duarte AWF, Passarini MRZ, Ruiz ATG, Franco CH, Moraes CB, et al. Bacteria from Antarctic environments: diversity and detection of antimicrobial, antiproliferative, and antiparasitic activities. Polar Biol. 2018; 41:1505-1519.

15. Kumar L, Awasthi G, Singh B. Extremophiles: A novel source of industrially important enzymes. Biotechnol. 2011; 10:121-135.

16. Martinez-Rosales C, Castro-Sowinski S. Antarctic bacterial isolates that produce cold-active extracellular proteases at low temperature but are active and stable at high temperature. Polar Res. 2011; 30:7123-7128. 
17. Santiago M, Ramirez-Sarmiento CA, Zamora RA, Parra LP. Discovery, molecular mechanisms, and industrial applications of cold-active enzymes. Front Microbiol. 2016; 7:1408.

18. Petrova IS, Vintsyunayte MN. [Determination proteolytic activity. Enzyme preparations of microbial origin]. Prikl Biokhim Mikrobiol. 1966; 2(1):322-327. Russian.

19. Trombridg GO, Moon HD. Purification of human elastase. Proc Soc Exp Biol Med. 1972; 141(3):928-931.

20. Dalmaso GZL, Ferreira D, Vermelho AB. Marine Extremophiles: A source of hydrolases for biotechnological applications. Mar Drugs. 2015; 13(4):1925-1965.
21. Ferres I, Amarelle V, Noya F, Fabiano E. Identification of Antarctic culturable bacteria able to produce diverse enzymes of potential biotechnological interest. Adv Polar Sci. 2015; 26(1):7179 .

22. Larsbrink J, Izumi A, Ibatullin F, Nakhai A, Gilbert HJ, Davies GJ, et al. Structural and enzymatic characterisation of a glycoside hydrolase family 31 alpha-xylosidase from Cellvibrio japonicus involved in xyloglucan saccharification. Biochem J. 2011; 436(3):567-580.

23. Jabbour D, Borrusch MS, Banerjee G, Walton JD. Enhancement of fermentable sugar yields by alpha-xylosidase supplementation of commercial cellulases. Biotechnol Biofuels. 2013; 6:58

Received 29.09.2020 